Preface

\title{
Editorial Compilation XI
}

\author{
Emmanuel J. Favaloro, PhD FFSc (RCPA) ${ }^{1}$ Giuseppe Lippi, MD ${ }^{2}$ (1) \\ 1 Department of Haematology, Institute of Clinical Pathology and \\ Medical Research (ICPMR), Sydney Centres for Thrombosis and \\ Haemostasis, Westmead Hospital, Westmead, Australia \\ 2 Section of Clinical Biochemistry, University of Verona, Verona, Italy \\ Semin Thromb Hemost 2022;48:127-131.
}

Welcome to the latest issue of Seminars in Thrombosis and Hemostasis (STH) published under the "banner" of "Editorial Compilation," this being the 11th such issue (-Table 1 ). Although Seminars in Thrombosis and Hemostasis is historically a theme-driven publication, ongoing opportunities emerge to disseminate wide-ranging contributions of current interest or controversy, and which do not straightforwardly suit an ongoing themed issue. We also require a medium for enabling publication of "unsolicited" manuscripts, as well as additional contributions from our Eberhard F. Mammen Young Investigator Award winners (-Table 2). As is now standard for this compilation series, the current issue contains a mixture of articles that comprises the above elements, as well as broadly fitting within the standard themes of "thrombosis" and "bleeding."

This issue begins with a contribution from Szabó et al, on laboratory approaches to test the function of antiphospholipid antibodies (aPLs). ${ }^{1}$ Antiphospholipid syndrome (APS) is a systemic autoimmune disorder characterized by the presence of aPLs (i.e., anti- $\beta_{2}$-glycoprotein I, anticardiolipin, and lupus anticoagulant [LA]). Everyday practice in terms of laboratory diagnostics of APS includes aPLs assessment and well-known functional assays for LA, in turn using various tests. According to recent guidelines, the recommended method for LA identification or exclusion is based on the Russell Viper Venom test and a sensitive activated partial thromboplastin time assay. Despite the fact that LA can be quantified in laboratory practice in this way, LA is still used as a binary parameter that is just one of the risk factors of thrombosis in APS. Currently, there are no other functional assays to routinely assess the risk of thrombosis in APS. It is well-known that APS patients display a wide range of clinical outcomes, although they may express very similar laboratory findings. One way to solve this dilemma could be if antibodies could be further delineated using more advanced functional tests. Therefore, the authors review the diagnostic

Address for correspondence Emmanuel J. Favaloro, PhD FFSc (RCPA), Department of Haematology, Institute of Clinical Pathology and Medical Research (ICPMR), Westmead Hospital, Westmead 2145 Australia (e-mail: emmanuel.

favaloro@health.nsw.gov.au). approaches to test the function of aPLs. They further discuss how thrombin generation assays and rotational thromboelastometry tests can be influenced by LA, and how experimental methods, such as flow cytometric platelet activation, surface plasmon resonance, or nano differential scanning fluorimetry can bring us closer to the puzzling interaction of aPLs with platelets as well as with their soluble protein ligand. These novel approaches may eventually enable better characterization of aPL, and provide also better linkage to APS pathophysiology.

This issue of STH continues with a review from Gary Moore on the use of snake venoms in diagnostic hemostasis and thrombosis. ${ }^{2}$ Snake venoms have evolved primarily to immobilize and kill prey, and consequently, they contain some of the most potent natural toxins. Part of that armory is a range of hemotoxic components that affect every area of hemostasis, which have been harnessed to great effect in the study and diagnosis of hemostatic disorders. The most widely used are those that affect coagulation, such as thrombin-like enzymes unaffected by heparin and direct thrombin inhibitors, which can help confirm or dispute their presence in plasma. The liquid gold of coagulation activators is Russell's viper venom, since it contains activators of factor $(F) X$ and FV. It is used in a range of clotting based assays, such as assessment of FX and FV deficiencies, protein $\mathrm{C}$ and protein $\mathrm{S}$ deficiencies, activated protein $C$ resistance, and probably the most important test for LA, the dilute Russell's viper venom time. Activators of prothrombin, such as oscutarin $C$ from Coastal Taipan venom and ecarin from saw-scaled viper venom, are employed in prothrombin activity assays and LA detection, and ecarin has a valuable role in quantitative assays of direct thrombin inhibitors. Snake venoms affecting primary hemostasis include botrocetin from the jararaca, which can be used to assay von Willebrand factor (VWF) activity, and convulxin from the cascavel, which can be used to detect deficiency of the platelet collagen receptor, (c) 2022. Thieme. All rights reserved. Thieme Medical Publishers, Inc., 333 Seventh Avenue, 18th Floor, New York, NY 10001, USA
DOI https://doi.org/ 10.1055/s-0041-1740151. ISSN 0094-6176.
Compilation XI; Guest Editors: Emmanuel J. Favaloro, PhD, FFSc (RCPA) and Giuseppi Lippi, MD 
Table 1 Past STH issues in the series "Editorial Compilation"

1. Favaloro EJ, Lippi G. Editorial Compilation I. Semin Thromb Hemost 2016;42(1):5-8.

2. Favaloro EJ, Lippi G. Editorial Compilation II. Semin Thromb Hemost 2016;42(6):599-602.

3. Favaloro EJ, Lippi G. Editorial Compilation III. Semin Thromb Hemost 2017;43(1):4-7.

4. Favaloro EJ, Lippi G. Editorial Compilation IV. Semin Thromb Hemost 2017;43(6):549-552.

5. Favaloro EJ, Lippi G. Editorial Compilation V. Semin Thromb Hemost 2018;44(3):193-196.

6. Favaloro EJ, Lippi G. Editorial Compilation VI. Semin Thromb Hemost 2019;45(1):5-9.

7. Favaloro EJ, Lippi G. Editorial Compilation VII. Semin Thromb Hemost 2019;45(5):429-432.

8. Favaloro EJ, Lippi G. Editorial Compilation VIII. Semin Thromb Hemost 2020;46(4):393-397.

9. Favaloro EJ, Lippi G. Editorial Compilation IX. Semin Thromb Hemost 2021;47(1):6-10.

10. Favaloro EJ, Lippi G. Editorial Compilation X. Semin Thromb Hemost 2021;(7):754-758.

Table 2 Past STH editorials related to Eberhard F. Mammen award announcements

1. Favaloro EJ. Welcome to a Special Issue of Seminars in Thrombosis and Hemostasis-The Closing Issue for 2008. Semin Thromb Hemost 2008; 34: 693-696

2. Favaloro EJ. A Tribute to Eberhard F. Mammen, M.D. (1930-2008). Semin Thromb Hemost 2008; 34: 703-708

3. Favaloro EJ. Welcome to the first issue of Seminars in Thrombosis and Hemostasis for 2009. Semin Thromb Hemost 2009; 35:1-2.

4. Favaloro EJ. Winners of the Inaugural Eberhard F. Mammen Award for Most Popular Article. Semin Thromb Hemost 2009; 35 : 587-590

5. Favaloro EJ. Editorial. 2009 Eberhard F. Mammen Young Investigator Award Winners. Semin Thromb Hemost 2010; 36: 469-470

6. Favaloro EJ. Winners of the 2010 Eberhard F. Mammen Award for Most Popular Article during 2008-2009. Semin Thromb Hemost 2010;36(7):685-92.

7. Favaloro EJ. 2011 Eberhard F. Mammen award announcements. Semin Thromb Hemost 2011;37(5):431-9.

8. Favaloro EJ. 2012 Eberhard F. Mammen award announcements. Semin Thromb Hemost 2012;38:425-32.

9. Favaloro EJ. 2013 Eberhard F. Mammen award announcements. Semin Thromb Hemost 2013;39:567-74.

10. Favaloro EJ. 2014 Eberhard F. Mammen award announcements: Part I - most popular articles. Semin Thromb Hemost 2014;40(4):407-12.

11. Favaloro EJ. 2014 Eberhard F. Mammen Award Announcements: Part II - Young Investigator Awards. Semin Thromb Hemost 2014;40(7):718-23.

12. Favaloro EJ. 2015 Eberhard F. Mammen Award Announcements: Part I-Most Popular Articles. Semin Thromb Hemost 2015;41(7):673-9.

13. Favaloro EJ. 2015 Eberhard F. Mammen Award Announcements: Part II-Young Investigator Awards. Semin Thromb Hemost 2015;41(8):809-15.

14. Favaloro EJ. 2016 Eberhard F. Mammen Award Announcements: Part I - Most Popular Articles. Semin Thromb Hemost 2016;42(4):325-30.

15. Favaloro EJ. 2016 Eberhard F. Mammen Award Announcements: Part II-Young Investigator Awards. Semin Thromb Hemost 2017;43(3):235-241.

16. Favaloro EJ. 2017 Eberhard F. Mammen Award Announcements: Part I-Most Popular Articles. Semin Thromb Hemost 2017;43(4):357-363.

17. Favaloro EJ. 2017 Eberhard F. Mammen Award Announcements: Part II-Young Investigator Awards. Semin Thromb Hemost 2018;44(2):81-88.

18. Favaloro EJ. 2018 Eberhard F. Mammen Award Announcements: Part I-Most Popular Articles. Semin Thromb Hemost 2018;44(3):185-192.

19. Favaloro EJ. 2018 Eberhard F. Mammen Award Announcements: Part II-Young Investigator Awards. Semin Thromb Hemost 2019;45(2):123-129.

20. Favaloro EJ. 2019 Eberhard F. Mammen Award Announcements: Part I-Most Popular Articles. Semin Thromb Hemost 2019;45(3):215-224.

21. Favaloro EJ. 2019 Eberhard F. Mammen Award Announcements: Part II-Young Investigator Awards. Semin Thromb Hemost 2020;46(2):105-113

22. Favaloro EJ. 2020 Eberhard F. Mammen Award Announcements: Part I-Most Popular Articles. Semin Thromb Hemost 2020;46(4):383-392.

23. Favaloro EJ. 2020 Eberhard F. Mammen Award Announcements: Part II-Young Investigator Awards. Semin Thromb Hemost 2021;46(3): 229-237.

24. Favaloro EJ. 2021 Eberhard F. Mammen Award Announcements: Part I-Most Popular Articles. Semin Thromb Hemost 2021;47(5):467-476.

glycoprotein VI. This article takes the reader to every area of the diagnostic hemostasis laboratory to appreciate the myriad applications of snake venoms available in diagnostic practice.
Next is a contribution on dysfibrinogenemia by Bor et $\mathrm{al}^{3}{ }^{3}$ specifically looking at the potential impact of genotype on thrombosis or bleeding. The congenital dysfibrinogenemias, most often associated with bleeding disorders, encompass 
mutations in the aminoterminal end of fibrinogen $\alpha$-chain consisting of Gly17-Pro18-Arg19-Val20, known as knob A, which is a critical site for fibrin polymerization. Here the authors review the studies reporting dysfibrinogenemia due to mutations affecting fibrinogen knob A and identified 29 papers. The number of reports on dysfibrinogenemias related to residues Gly17, Pro18, Arg19, and Val20 are 5, 4, 18, and 2 , respectively. Dysfibrinogenemias related to residues Gly17, Pro18, and Val20 are exclusively associated with bleeding tendency. However, the clinical picture associated with dysfibrinogenemia related to residue Arg19 varies, with most patients suffering from a higher risk of bleeding, but also transitory ischemic attacks and retinal thrombosis may occur. The reason for this variation is unclear. To elaborate the genotype-phenotype associations further, the authors studied a Danish family with knob A related dysfibrinogenemia caused by the A $\alpha$ Arg19Gly (p.Arg19Gly) mutation using whole-exome sequencing and fibrin structure analysis. This family is the first reported carrying the p.Arg19Gly mutation combined with one or more single-nucleotide polymorphisms (SNP)s in FGA, FGB, and/or FGG, and increased fibrin fiber thickness and fibrin mass-length ratio suffering from pulmonary emboli, thus suggesting that compound genotypes may contribute to the thrombogenic phenotype of these patients. This review, accordingly, focuses on significance of SNPs, compound genotypes, and fibrin structure measures affecting the genotype-phenotype associations in fibrinogen knob A mutations.

Next in this issue is a review on the role of fibrin(ogen) in wound healing and infection control, by Kearney et al. ${ }^{4}$ This represents a contribution from a past winner of a Young Investigator award, Fraser Macrae. ${ }^{5}$ Fibrinogen is one of the most abundant plasma proteins and plays a key role in hemostasis. Fibrinogen is also an important modulator of wound healing and host defense against microbes. Initially fibrin(ogen) acts as a provisional matrix supporting incoming leukocytes and acting as reservoir for growth factors. It later goes on to support reepithelialization, angiogenesis, and fibroplasia. Importantly, removal of fibrin(ogen) from the wound is essential for wound healing to progress. The authors also discuss how fibrin(ogen) functions through several mechanisms to protect the host against bacterial infection; that is, by providing a physical barrier, entrapment of bacteria in fibrin(ogen) networks and by directing immune cell function. The central role of fibrin(ogen) in defense against bacterial infection has made it a target of bacterial proteins, evolved to interact with fibrin(ogen) to manipulate clot formation and degradation for the purpose of promoting microbial virulence and survival. Further understanding of the dual role of fibrin(ogen) in wound healing and infection could provide novel means of therapy to improve recovery from surgical or chronic wounds and help to prevent infection from highly virulent bacterial strains, including those resistant to antibiotics.

Next, is a review by Maphumulo and Pretorius, on the role of circulating microparticles (MP) in type 2 diabetes mellitus, in particular the associated implications for pathological clotting. ${ }^{6}$ Type 2 diabetes mellitus is a multifactorial chronic metabolic disease characterized by chronic hyperglycemia due to insulin resistance and deficient insulin secretion. The global diabetes pandemic relates primarily to type 2 diabetes mellitus, which is the most prevalent form, accounting for over $90 \%$ of all cases. Chronic low-grade inflammation, triggered by numerous risk factors and chronic activation of immune system, are prominent features of type 2 diabetes mellitus. Here, the authors highlight the role of blood cells (platelets, red, and white blood cells) and vascular endothelial cells as drivers of systemic inflammation in type 2 diabetes mellitus. In addition, the authors discuss the role of MP on systemic inflammation and hypercoagulation. Although once seen as inert by-products of cell activation or destruction, MPs are now considered a disseminated storage pool of bioactive effectors of thrombosis, inflammation, and vascular function. They have been identified to circulate at elevated levels in the bloodstream of individuals with increased risk of atherothrombosis or cardiovascular disease, two significant hallmark conditions of type 2 diabetes mellitus. There is also general evidence that MPs activate blood cells, express pro-inflammatory and coagulant effects, interact directly with cell receptors, and transfer biological material. MPs are considered major players in the pathogenesis of many systemic inflammatory diseases, so that they may be seen as potentially useful biomarkers of disease activity, not only of prognostic value, but may act as novel therapeutic targets.

Next is a review on coagulation abnormalities of autoimmune acquired FV deficiency, with a focus on Japan, by Ichinose et al. ${ }^{7}$ Coagulation FV is an essential cofactor of coagulation FX in the common pathway of coagulation, and severe FV deficiency leads to a bleeding tendency. Although both congenital and acquired FV deficiencies are widely recognized, FV deficiency also presents as an autoimmune disorder. A nationwide survey on autoimmune coagulation factor deficiencies conducted in Japan by the Japanese Collaborative Research Group identified 24 new patients with autoimmune FV deficiency in the past 5 years. Furthermore, the authors performed a literature search that confirmed that 177 additional cases reported in previous articles published from Japan. Patients with autoimmune FV deficiency in Japan were predominantly men, with age similar to those with other autoimmune coagulation factor deficiencies. Autoimmune FV deficiency was confirmed as a relatively mild type of bleeding diathesis, associated with lower mortality rate than that for autoimmune FV deficiency and other autoimmune coagulation factor deficiencies reported in previous studies. Patients with autoimmune FV deficiency had variable FV inhibitor titers and both neutralizing anti-FV autoantibodies and non-neutralizing counterparts. Although spontaneous resolution occurs in some patients, timely initiation of hemostatic and immunosuppressive therapies helps arresting the bleeding and eliminating anti-FV antibodies, thus resulting in a high cumulative recovery rate. Immunological anti-FV antibody detection is recommended to avoid missing autoimmune FV deficiency cases for the presence of non-neutralizing anti-FV autoantibodies. Further investigation is necessary to clarify the long-term 
prognosis and optimal management of autoimmune FV deficiency.

A review on postpartum hemorrhage (PPH) in patients with type 1 von Willebrand disease (VWD) follows by Pierce-Williams et al. ${ }^{8}$ Type 1 VWD is the most common subtype of VWD, comprising $75 \%$ of VWD patients. The authors provide a systematic review of type 1 VWD in pregnancy. Their objective was to evaluate the rate of $\mathrm{PPH}$ in patients with known type 1 VWD. The primary outcome was rate of PPH. Primary PPH was defined as a cumulative blood loss $\geq 1000 \mathrm{~mL}$, or blood loss accompanied by signs and symptoms of hypovolemia within 24 hours postpartum or requiring blood products. Secondary PPH was defined as significant bleeding 24 hours to 12 weeks postpartum. Relevant articles published in English pertaining to VWD and pregnancy were identified without any time or study limitations. Seven articles ( $n=144$ pregnancies) met the inclusion criteria. The rate of primary $\mathrm{PPH}$ was $4 / 144$ (2.8\%). The secondary PPH rate was reported in four studies, and occurred in $7 / 48$ pregnancies (14.6\%), ranging from 2 to 19 days postpartum. In conclusion, according to this systematic review, the frequency of primary PPH in pregnancies with known type 1 VWD is $2.8 \%$. This is similar to the overall $\mathrm{PPH}$ rates of $3 \%$ reported in the literature. Although the sample size was small, secondary PPH occurred in almost $15 \%$ of pregnancies, while in the overall obstetrical population this occurs in $\sim 1 \%$ of cases. Patients with known type 1 VWD may not be at increased risk of primary PPH, though they appear to bear increased risk of secondary $\mathrm{PPH}$.

Next is a systematic review and meta-analysis on the effect of remote ischemic conditioning on bleeding complications in surgery, by Krag et al. ${ }^{9}$ Remote ischemic conditioning is administered with an inflatable tourniquet by inducing brief, alternating cycles of limb ischemia and reperfusion. Remote ischemic conditioning possibly impacts the hemostatic system, and the intervention has been tested as protective therapy against ischemia-reperfusion injury and thrombotic complications in cardiac surgery and other surgical procedures. In the present systematic review and meta-analysis, the authors aimed to investigate the effect of remote ischemic conditioning on intraoperative and postoperative bleeding complications in meta-analyses of randomized controlled trials including adult patients undergoing surgery. A systematic search was performed on November 7, 2020 in PubMed, Embase, and the Cochrane Central Register of Controlled Trials. Randomized controlled trials comparing remote ischemic conditioning versus no remote ischemic conditioning in adult patients undergoing surgery that reported bleeding outcomes in English publications were included. Effect estimates with 95\% confidence intervals were calculated using the random-effects model for intraoperative and postoperative bleeding outcomes. Thirty-two randomized controlled trials with 3,804 patients were eligible for inclusion. Remote ischemic conditioning did not affect intraoperative bleeding volume (9 trials; 392 patients, 399 controls) with the effect estimate $-0.95(-9.90 ; 7.99) \mathrm{mL}$ $(p=0.83)$. Remote ischemic conditioning significantly reduced postoperative drainage volume ( 7 trials; 367 patients,
365 controls) with mean difference $-83.6(-134.9 ;-32.4)$ $\mathrm{mL}(p=0.001)$. The risk of reoperation for bleeding was reduced in the remote ischemic conditioning group (16 trials; 838 patients, 839 controls), albeit not significantly, with relative risk of $0.65(0.39 ; 1.09)(p=0.10)$. In conclusion, remote ischemic conditioning reduced postoperative bleeding measured by postoperative drainage volume in this meta-analysis of adult patients undergoing surgery.

The final full-length paper in this issue of STH is a historical review on protamine, and its journey from DNA to heparin neutralization to gene therapy by Jecko Thachil. ${ }^{10}$ Although protamine is now well recognized as a key heparin neutralizing agent, it was discovered over a century ago, during experiments performed to uncover the secrets behind heritability. Although protamine was discovered as a highly charged protein, it did not receive the attention it deserved until the dawn of insulin era, when it was used to create the neutral protamine Hagedorn formulation. Based on the same principles, protamine was identified to neutralize heparin and has since been used successfully for many years in cardiothoracic surgery. More recently, its clinical applications have extended to gene therapy. In this historical sketch, the journey from the discovery of protamine, onwards to heparin neutralization, and up to its utilization in genetic modulatory treatments is detailed.

As usual for these nonthematic issues of STH, we complete the issue with some correspondence. First, Guillermo Ruiz-Argüelle provides some background to the premise that nonalcoholic fatty liver disease may cause thrombocytopenia. ${ }^{11}$ Next, the team of Limami et al provide some data to support that PKC-delta-dependent pathways contribute to the exacerbation of the platelet activity in Crohn's diseases. ${ }^{12}$ Next, Horneff et al $^{13}$ provide a commentary on a recently published paper in $\mathrm{STH},{ }^{14}$ around enhanced half-life recombinant FVIII concentrates for hemophilia A, and namely insights from pivotal and extension studies; this commentary is followed by a reply ${ }^{15}$ from the authors of the previous paper. ${ }^{13}$ Next, the team of Chen et al describes an interesting case of a parturient patient with hereditary thrombotic thrombocytopenic purpura. ${ }^{16}$ Finally, for this issue of STH, Thachil et al provide a thought provoking discussion on why "the love of blood" in Haemophilia? ${ }^{17}$

We once again thank all the authors to this latest issue of "Editorial Compilations" for their original and comprehensive contributions, and we hope our readership enjoys this latest instalment in this series.

Conflict of Interest

None declared.

\section{References}

1 Szabó G, Antal-Szalmás P, Kerényi A, Pénzes K, Bécsi B, Kappelmayer J. Thrombin: Laboratory approaches to test the function of antiphospholipid antibodies. Semin Thromb Hemost 2022;48 (02):132-144

2 Moore GW. Snake venoms in diagnostic haemostasis and thrombosis. Semin Thromb Hemost 2022;48(02):145-160 
3 Bor MV, Feddersen S, Pedersen IS, Sidelmann JJ, Kristensen SR. Dysfibrinogenemia - potential impact of genotype on thrombosis or bleeding. Semin Thromb Hemost 2021;48(02):161-173

4 Kearney KJ, Ariëns RAS, Macrae FL. The role of fibrin(ogen) in wound healing and infection control. Semin Thromb Hemost 2021;48(02):174-187

5 Favaloro EJ. 2018 Eberhard F. Mammen Award Announcements: Part II-Young Investigator Awards. Semin Thromb Hemost 2019; 45(02):123-129

6 Maphumulo SC, Pretorius E. Role of circulating microparticles in type 2 diabetes mellitus: implications for pathological clotting. Semin Thromb Hemost 2022;48(02):188-205

7 Ichinose A, Osaki T, Souri M. A review of coagulation abnormalities of autoimmune acquired factor $\mathrm{V}$ deficiency with a focus on Japan. Semin Thromb Hemost 2022;48(02):206-218

8 Pierce-Williams RAM, Makhamreh MM, Blakey-Cheung S, Gao Z, Al-Kouatly HB. Postpartum hemorrhage in patients with type 1 von Willebrand disease: A systematic review. Semin Thromb Hemost 2022;48(02):219-228

9 Krag AE, Hvas CL, Kiil BJ, Hvas A-M. Effect of remote ischemic conditioning on bleeding complications in surgery: a systematic review and meta-analysis. Semin Thromb Hemost 2021;48(02): 229-239

10 Thachil J. Protamine - the journey from DNA to heparin neutralisation to gene therapy. Semin Thromb Hemost 2022;48(02):240-243
11 Guillermo Ruiz-ArgüelleJ. Démonstration de faisabilité: Non-alcoholic fatty liver disease may cause thrombocytopenia. Semin Thromb Hemost 2022;48(02):244-245

12 Limami Y, Senhaji N, Zaid N, et al. PKC-delta-dependent pathways contribute to the exacerbation of the platelet activity in Crohn's disease. Semin Thromb Hemost 2022;48(02):246-250

13 Horneff R, Bystrická L, Santagostino E, Lethagen S, Casiano S. Comment on "Enhanced Half-Life Recombinant Factor VIII Concentrates for Hemophilia A: Insights from Pivotal and Extension Studies". Semin Thromb Hemost 2022;48(02):251-252

14 Di Minno MND, Di Minno A, Calcaterra I, Cimino E, Dell'Aquila F, Franchini M. Enhanced half-life recombinant factor VIII concentrates for hemophilia A: insights from pivotal and extension studies. Semin Thromb Hemost 2021;47(01):32-42

15 Di Minno MND, Di Minno A, Calcaterra I, Cimino E, Dell'Aquila F, Franchini M. Enhanced half-life recombinant factor VIII concentrates for hemophilia A: final results from extension studies. Semin Thromb Hemost 2022;48(02):253-255

16 Chen JK, Tang N, Wang X, Huang M, Zhang C. A case of parturient with hereditary thrombotic thrombocytopenic purpura: case report of a novel variant. Semin Thromb Hemost 2021;48(02): 256-261

17 Thachil J, Triantafillou M, Bristogiannis S. Why 'the love of blood' in Haemophilia? Semin Thromb Hemost 2022;48(02): 262-264 